New Zealand Journal of Industrial Relations, 1982, 7 145-156

\title{
The National Research Advisory Council and some counsel for research against National
}

\author{
Murray Pereira*
}

This article examines the Report of the National Research Advisory Council's Working Party on Research into Employment with Special Emphasis on Youth Unemployment. An analysis is made of its recommendations and the reception given the Report upon its unofficial release in July 1981.

The National Research Advisory Council (NRAC) report concerning unemployment is one which few of us would have heard about if the Auckland Star had not seen fit to give the leaked report's estimate a banner headline, which read: "Report tells grim story on workforce. 150,000 feared jobless" (4 July 1981). Most of us could not give the report its full title: Report of the Working Party on Research into Employment with Special Emphasis on Youth Unemployment. Such "leaks" are becoming increasingly common both here and elsewhere. As E.P. Thompson has recently put it with respect to the United Kingdom: "readers find themselves sprayed from on high by conflicting official leaks" (1980, p.261). A Treasury report concerning New Zealand for instance forecasting 300,000 unemployed by the mid-1980s hit the headlines early $1979^{1}$. In the United Kingdom "Two million jobless report hushed-up" was The Observer's main headline on 17 June 1979 which announced that that Treasury's own detailed forecasts for employment and unemployment had not yet reached the Department of Employment. By September 1980 "the increase in redundancies notified has been so great that the year's total is likely to be at least twice, if not three times, the number for 1979" (Showler and Sinfield, 1981, p.241). By August 1981 an unofficial figure of 3,000,000 was suggested which did not meet with official substantiation until January 1982. In New Zealand the controversies over official statistics are with good reason given the disparity between census night numbers "unemployed and seeking work" and those "registered" as unemployed at the same time. For example 26,337 stated they were "unemployed and looking for work" on the 1976 Census whereas only 5,256 were actually registered as unemployed with the Department of Labour. Such disparities have a long history in New Zealand (see Easton, 1979, pp.48-49) although the disparity seems to be lessening with each census as unemployed people become more inclined to register. Evidence for this can be found in the provisional sample estimates for the 1981 population census. Based on a 10 percent sample of private dwellings and a complete coverage of non-private dwellings 60,860 were "unemployed and seeking work" on Census night whereas 47,464 were registered with the Department of Labour. Although this represents a decline in the disparity it represents an overall rise of 138 percent during the 1976-1981 intercensal period (Labour and employment gazette, 1 March 1982).

* Lecturer in Sociology, University of Auckland.

1. See various newspapers during April 1979. 


\section{The National Research Advisory Council}

The NRAC is a government appointed body established by Act of Parliament in 1963 and is responsible for advising government on priorities for science. It consists of up to twelve members. The Director-General of the DSIR the Secretary to the Treasury are all ex-officio members, although in practice the Secretary to the Treasury is usually represented by a nominee drawn from the Assistant Secretary level. The council also has an observer from the State Services Commission. The remaining members (up to nine of them) are government appointees drawn from outside the public sector. A new chairman was appointed in 1979, Mr A.W. Mackney, Managing Director of New Zealand Forest Products Ltd. The servicing of the Council and its committees is carried out by a secretariat of six public servants and is the responsibility of the State Services Commission.

The Council's work is conducted through a system of four permanent advisory committees: Primary Production, Manufacturing and Processing, Environment and Energy, and Social Sciences. The last of these, Social Sciences, was added only in 1976 and is currently chaired by G.S. Fraser, Professor of Sociology at Massey University. The 1980 expenditure available for social science research contracts amounted to $\$ 350,000$. The fund is administered by the Social Sciences Research Fund Committee (SSRFC), the Executive Officer being Dr Judith Johnson who complained at the 1981 Mental Health Foundation and N.Z. Psychological Society symposium on unemployment that few requests for funds had been received by the SSRFC for research proposals concerning the present unemployment crisis. A grant was awarded in 1980 to Ms S. Shipley, Massey University, to study "The extent, nature and social effects of unemployment among women in Palmerston North City". Part of Shipley's research concerned the unwanted economic dependence on men that unemployment among women can create.

In addition to its committees, the Council also uses ad hoc "working parties" for special projects and increasing use has been made of this approach over the last few years. During the year ended 31 March 1980 for example the working parties' reports on science administration, research evaluation and review, and research contracts were drafted. Work on commercial fisheries, industrial relations, and employment research was nearly complete. The Council's practice has been to circulate working party reports for comments before determining its advice to the Minister on the subject under review.

Ovenden $(1979$, p.126) has pointed out that a large proportion of sicence research money which the NRAC allocates via its science budget goes to just four government departments, Agriculture and Fisheries, the Forest Service, the DSIR, and the Ministry of Transport. In the year ended 31 March 1980 this amounted to $\$ 95,190,000$ out of a total $\$ 113,225,000$.

Ovenden (1979) has also pointed out that confusion exists over whether or not the NRAC sees its role as one of deriving a policy for science or a science for policy and this is indeed evident in the Annual Report for 1980 which has it that
As there is a limit to resources and no limit to possible research proposals, choices have to be made. It is NRAC's responsibility to advise the Government on relative priorities of research programmes. How can a research programme in plant breeding be compared with programmes in industrial relations or manufacturing? What criteria should be used? (NRAC, 1980, p.3).

The report continues that the Council's first report in 1965 tried to answer these same questions and that fifteen years later the Council still had "no neat and tidy solution" although

The criterion must, of course, change to take account of changing Government's policies in response to new circumstances. The present emphasis on factors such as contribution to export development, import substitution, and employment, has become part of the criteria for programme evaluation. It is 
clearly important to devote a large proportion of science resources to work directed towards these goals (NRAC, 1980, pp.3-4, my emphasis). ${ }^{2}$

Whether or not the Council asks itself from time to time if the "changing Government's policies" themselves require rigorous policy analysis by independent nonpartisan examiners is not evident in the report. However one thing is for sure, the Council is not aware of, nor does it maintain a rigorous distinction between an ethic of ultimate ends and one of responsibility, although its own policy would seem to fall on the side of the former:

NRAC has accepted the Government's direction to intensify its endeavours to guide scientific work along lines that are relevant to economic development (NRAC, 1980, p.3).

The Council seems quite unconcerned with what has been called the "paradox of consequences" which occurs when the outcomes of particular plans and policies do not live up to their original promise or are entirely different from the original intentions. Thus it is to be anticipated that a report which recommends that research should be directed at the causes and consequences of economic crisis may get short shrift from such a body. Which is exactly what happened to the Working Party's report. Although the Council considered that the report "has value in drawing attention to the existing employment research data base and supports the report's proposal for better co-ordination of research" it has "reservations about the 'Background' section of the report and the recommended research priorities". Unfortunately the essential parts of the report embody exactly these two sections and so it was therefore made available without the Council's formal endorsement of its content and recommendations. ${ }^{3}$ Ovenden $(1979$, p.139) has mentioned that one of the most disturbing features of those who subscribe to a science for policy orientation when conceptualising science and research in the public policy arena of societies such as ours, is that they tend to conceive science "entirely as a master perceives a servant or slave." Comments such as those of the Prime Minister's during the furore following the Report's unofficial release, to the effect that the Report was "garbage" (NZ Herald, 7 July 1981) would seem to bear this attitude out quite nicely. For one would not attempt to be so insultingly dismissive to scientists one respected above the status of mere servants to the State.

\section{Report of the Working Party on Research into Employment with Special Emphasis on Youth Employment}

That unemployed people need more work rather than more research does not pre-empt in any way what follows, as often lack of the latter can certainly add to the growth of the former. For instance there have been a variety of schemes involving government subsidies to help specific groups of people. There is a danger that some employers may come to regard certain groups of people as acceptable only if they are offered a subsidy. Such employers may become increasingly resistant to employing the likes of school leavers without a subsidy and this is of course a complete reversal of the intended purposes of such subsidies in the first place. ${ }^{4}$

2. Note the "Government's" and not "Governments" " meaning that the likes of the NRAC has to contend with the ever changing and differing policy orientations within the same government rather than with the policies of differing governments. One would like to think that the NRAC was venturing some critical observation albeit mild with this usage?

3. The citations in this paragraph are those of A.W. Mackney, NRAC Chairman, to be found in a covering note to the released Working Party's report (NRAC, 1981).

4. There has been some research into such possibilities overseas (see e.g. Hill, in Showler and Sinfield (Eds), 1981, pp.89-121; Field and Winyard, in Field, 1977, pp.125-137) and even less in New Zealand (but see Forer, 1980, pp.33-37). 


\section{Murray Pereira}

When the NRAC in its 1980 report admits that it has to move its criteria in tandem with "changing Government's policies" it is speaking to the ill-defined, adhocratic and shortsighted processes of policy formation and execution which exists in New Zealand. For instance, the "Guide to employment and training assistance now available" in the document, Jobs and people (1981, pp.28-31) which the Government apparently produced in response to the NRAC Working Party's report provides sufficient evidence of this with respect to present employment policy. Only one of the twenty four schemes outlined mentions that the form of assistance is "to increase permanent employment" (my emphasis). Predictably this is in the Farm Employment Scheme (FES). Thus the following terms of reference for the working party were wholly commendable:

i. To assess the data base currently available to measure the characteristics and dynamics of the labour market with particular reference to unemployment and longer term employment options;

ii. to consider the nature, extent and adequacy of the existing data base and interpretations it permits;

iii. to review the present state of knowledge on the "causes" and "effects" of unemployment;

iv. to evaluate the state of evaluation of programmes relevant to the labour market, particularly unemployment prevention strategies and unemployment remediation projects;

v. in the light of (i), (ii), (iii) and (iv) above, to identify research needed, to determine priorities and comment on the conditions thought necessary to undertake it (NRAC, 1981, p.26).

To undertake this task the NRAC selected seven representatives from the academic and public sectors. The Working Party was convened by Professor Ray Adams, Professor of Education at Massey University. The other members were: David Imray, Director of Research and Planning, Department of Labour; Alf Kirk, Research Officer at the Federation of Labour; Fraser McDonald, Senior Advisory Officer with the Vocational Training Council; Ian Shirley, a senior lecturer in Sociology and Social Work at Massey University; Suzanne Snively, an economist from the Victoria University of Wellington and Stewart Ransom, a senior lecturer in Business Studies at Massey..$^{5}$ The Working Party met ten times between April 1979 and April 1980. It had discussions with 51 organisations comprising among others, government departments, universities, technical institutes, trade councils, employers', farmers' and manufacturers' federations, the Reserve Bank, local committees on unemployment, the National Youth Council and the Prime Minister's Department. As well it held public meetings with various work trusts, church social services, service clubs and city councils. Only an issue as pervasive as unemployment could give rise to such a wide range of concerned statutory, independent and voluntary groups. The Working Party's attempt to pool the knowledge such groups represent was a timely strategy given its terms of reference.

The Working Party also circulated an open-ended questionnaire to an equally wide range of organisations in order to determine the existing statistics available on employment, unemployment and the labour market generally; the uses to which such data was being put; what further data and what uses such data could be put to in the future; and what relevant research activity they were presently engaged in. It is unfortunate that the report the NRAC finally released does not contain a detailed analysis of this questionnaire which would be useful to both researchers and policy makers working in this area and provides only "the general impressions gained from the responses". It seems though that some of the organisations that received the questionnaire took more time and care in responding to the Working Party's draft report which the NRAC later circulated than to the initial questionnaire.

5. The "Massey connection" which emerges with respect to the Chairmanship of the NRAC Social Sciences Committee, the preponderance of Massey academics on the Working Party and the fact that the SSRFC made a grant for a study of unemployment in Palmerston North is perhaps worthy of a network analysis of the social processes involved in research innovation (see Mulkay and Melic, 1980). 
The report was completed in April 1980 and then circulated by the NRAC around sixteen departments and organisations for comments as is the practice already described and then referred it back to Council. In fact this is the sum of NRAC's acknowledgement of the report in its own 1981 Annual Report: "completed reports on employment/unemployment research and industrial relations research (another working party) have been circulated for comment and referred back to council" (NRAC, Annual Report, 1981, p.11). Given that this was a year after "work on ... employment research ... was nearly complete" (NRAC, 1980, p.11) it would seem that the report was unacceptable to the Council and was either awaiting official approval or had been mothballed. The vociferous and pugnacious parliamentary debate following the report's unofficial release in July 1981 gives credence to this latter possibility. For example see NZPD 438(12), p.1474 where the Rt. Hon. R.D. Muldoon can be found recalling the Working Party's membership

The people I can recall are a Professor Adams from Massey University, who has not been prepared to defend his report in public; Alf Kirk, an economist with the Federation of Labour; a man named Shirley, from Massey University who is well known for his anti-Government political comments; a woman named Snively, who is the wife of a fellow called Ian Fraser; and a man from -

The man "named Shirley" subsequently claimed $\$ 50,000$ against Mr Muldoon for linking his name with the leaked report in a television programme. Presumably the sub judice issue was whether or not Ian Shirley "leaked" the Report in the first place. That the Report was first reported in the National Business Review (NBR) as early as 23 March 1981 and cited the controversial figure of 150,000 unemployed speaks to the potency of a Saturday night headline.

To anyone familiar with the growing literature concerning unemployment the report reads as a mild and cautious piece of timely advice. ${ }^{6}$ Although much was made of the Report's estimate of 150,000 unemployed or "guesstimate" as the Minister of Labour, Mr Bolger, called it (NZ Herald, 6 July 1981) the Report does not belabour the controversies that surround labour market statistics. Instead it speaks directly to the fact that unemployment is a social problem endemic in an economic system such as New Zealand's, and as such, concerns people not statistics. It is ironic that the Government's Jobs and people booklet mentions that unemployment is about people only once (in its title!) and continues to produce numbers for thirty odd pages. In contrast the NRAC Report takes this premise as its starting point and endeavours to outline the human misery unemployment can cause. Thus:

There is reason to believe that at the personal level, unemployment brings a whole host of attendant problems - ill health, psychological disturbance, delinquency, crime and other malfunctions that can be broadly classified as personal, family and social breakdown. However, even here, what causes these to come about and what therefore might effectively be done to alleviate the distress, remains unclear (NRAC, 1981, p.14).

6. Whilst it is not intended that this footnote become an extended bibliographical essay the more important recent publications are Casson (1979), Field (1977), Hayes and Nutman (1981), Jenkins and Sherman (1979), Showler and Sinfield (1981), Sinfield (1981), Windschuttle (1979). In New Zealand the literature is small but growing: Brae (1978), Gidlow (1979), Shannon and Webb (1980) and Walsh (1978). The Working Party should take some solace in the fact that in June 1980 the U.S. National Advisory Council on Economic Opportunity, under the Chairmanship of Arthur I. Blaustein, submitted its Twelfth Report, Critical choices for the eighties, to President Carter. It "described the myths and got to the realities" of poverty and unemployment in that country. The report is a hard hitting and impressive document. As the editors of Dissent who published some excerpts from the report state: "Most likely the Carter administration would not have made significant use of the facts and recommendations in the Report. It is virtually certain that the new Reagan administration will ignore them" (Dissent, 1981, p.164). 
The Report's "Background" section is replete with such seemingly unsubstantiated assertions. Evidence that such claims can be substantiated is to be found in the Report's extensive appendix. This abstracts over ninety published and unpublished articles from a search of New Zealand literature on employment and unemployment available prior to September 1979, undertaken for the Working Party under the auspices of a Temporary Employment Scheme. Some cross-referencing would have prevented the charge of "unsubstantiated assertion" which critics eagerly complained about. The rather harsh criticism that came from T.K. McDonald, the Director of the New Zealand Institute of Economic Research, and the Treasury to the effect that the report was "generally vague, imprecise, superficial and subjective" and "if it was handed to me as a PhD thesis I'd think twice about it" (NBR, 23 March 1981) no doubt result from the fact that the Working Party did not see their terms of reference as a chance to model unemployment and produce a string of core variables and logarithmic equations. Anyhow it would seem that the economists who made these fault-finding statements certainly do not share Keynes' expressed faith in the ultimate triumph of ideas over vested interests. Although the Working Party was obviously at pains to couch the language of its report in a discussion appropriate to such an immediate human issue perhaps it would have received a more sympathetic hearing if it had adequately sourced and referenced many of its substantive claims. Despite the Report's introduction which says that "we have deliberately avoided using several academic conventions that would be expected in scholastic documents" it does not say why, apart from the claim that "the treatment of employment/unemployment in its full detail and complexity would require a major (and possibly tedious) treatise" (NRAC, 1981, p.3).

The background section to the Report is predicated on an interdisciplinary approach which does not "credit economics, sociology, education, or any other single scientific discipline, with having a monopoly of relevant knowledge" (NRAC, 1981, p.3). The Working Party's analysis then begins with a rather cursory discussion concerning the extent of unemployment and points out that official statistics do not provide a true picture of the labour market. If the number of people in job creation schemes, statistics were generated in the same way as in some other OECD countries, ${ }^{7}$ and if those who do not register as unemployed for one reason or another, and those skilled workers who have migrated from New Zealand were to be taken into account then: "Estimates of the true unemployment figure go as high as 150,000 " (NRAC, 1981, p.5). An enquiry as to whether unemployment is a function of individual inadequacy or the product of contradictions within the social structure follows. The Report's conclusion is that

If only two or three hundred people were employed in a country the size of
New Zealand and there were job vacancies, then we might well agree that the
problem lies with the individual who is a reluctant worker or unemployable
because of some personal condition. But when 8 percent of the workforce is
unemployed (based on an estimate of those "actively seeking work") then the
very structure of opportunities has been fractured. The problem is no longer
the result of individual inadequacy, deviancy or ignorance but rather it
emanates from social, economic and political forces beyond individual control
(NRAC, 1981, p.11).

The figure of 8 percent is not a mere stab in the dark as some would like to believe and is comparable with the Auckland City Council's survey of 3,000 households in the Auckland isthmus in 1980 . According to this study a total of 40,500 people were unemployed at a time when only 8,000 were registered as such which represents 7.6 percent of the labour force (Auckland City Council, 1980, p.6). The report continues with a discussion of the social consequences of unemployment and points out that it is both wasteful and costly

7. See OECD (1979) for a discussion and comparative analysis of how the different OECD countries generate their official employment and unemployment statistics. The New Zealand Department of Labour has made substantial changes in the collation of unemployment statistics since this survey was taken, although there is as yet no regular household survey to complement the unemployment register as exist in other OECD countries. 
in terms of human resources, the direct and indirect costs of supporting unemployed people, and in terms of the "consequential costs resulting from a related increase in illhealth, psychological disturbance, delinquency, crime and social unrest" (NRAC, 1981, p.5).

The Report does not collapse cause and consequence which is the approach orthodox economic accounts and political analyses take with respect to pressing social problems. Under such a perspective, policies like grandiose "thinking big" become universal panaceas without any consideration of the possible "paradox of consequences" referred to earlier.

Although the Report does not launch a frontal assault on social policy in terms of the possible unanticipated and unintended results of such schemes as "new education and welfare programmes, new industry developments, new technologies, new economic plans" it asks "are we travelling in the right direction?"'(NRAC, 1981, pp.1, 16). Increasingly the very question sparks off the ire of those who are on the right of the political spectrum. As the report points out "change, especially in people's entrenched behaviours, attitudes and beliefs, comes slowly and with difficulty" (NRAC, 1981, p.23).

The Report is at pains to discredit and debunk the "natural" rate of unemployment hypothesis which posits that a degree of unemployment is necessary to discipline the work force at large. The supposed trade-offs between unemployment and inflation, wagelevels, profit-levels and the 'productive' new technologies are also examined although not very thoroughly. The attempt leads to the following conclusion:

\begin{abstract}
While it is clear that the unpleasant consequences of the existence of unemployment fall most heavily on the unemployed themselves, it is usually assumed that compensatory benefits will occur elsewhere. For example, it has been asserted that unemployment is required if industries are to become more efficient and therefore more profitable. There is behind such an assertion the acceptance of a "free market" philosophy which in its turn assumes that it is good to encourage efficient industries because they will best meet all the nation's economic needs. These assumptions disregard the wider social and political consequences. Furthermore, there is entrenched opposition to the free market philosophy to be found within the industrial section itself - as opposition to the removal of industrial subsidies and national tariff barrier, testifies (NRAC, 1981, p.15).
\end{abstract}

Little wonder that the Employer's Federation lamented the lack of representatives from the production sectors of the economy in the Working Party and said of the Report that "it gives us no joy at all to see the acceptance of a free-market philosophy questioned" (NBR, 23 March 1981). The Report continues to outline some problematic assumptions "about the policies of the political wing of government" (NRAC, 1981, p.15). Firstly, although policy remains committed to the objective of full employment it is not clear "how many unemployed are too many" or how current economic policies are to realise the goal of full employment. Government departments have no clear guidelines and often are left to define their own role with respect to policy which can lead to differing interpretations both of the nature of the problem and as to the desired "treatment". The resulting casualty is an increase in redundancies and unemployment. The Report then questions the assumption that the benefits of increased economic growth will "trickle down" to benefit all sectors of New Zealand society. Even if the growth rate does increase the Report asks what guarantee is there that this will change the nature or extent of unemployment or that the "benefits" will be equitably distributed. As the 1980 OECD Economic Survey of New Zealand put it “. . . substantial benefits will arise from large development projects and particularly the Maui natural gas field. While these developments may provide a more favourable climate for structural change through generating a degree of growth in real incomes, they are not a substitute for the necessary structural changes in New Zealand's economy" (OECD, 1980, p.41). The assumptions that an increased industrialisation of New Zealand's energy, forestry, fishing and horticultural resources and that the injection of foreign capital and technology that these require will reduce unemployment, increase economic growth, are viable and desired objectives are then examined. The Working 
Party "received no evidence to suggest that these questions have been addressed with any degree of clarity" (NRAC, 1981, p.17) and concludes that policy analysis must proceed on three levels, those of the individual, the labour market and society at large, or else:

.... it looks as if the nation is going to have to bear a substantial social and economic burden in the meantime in the interests of presumed future wealth. It also looks as if some sections of the community are going to have it tougher than others, and as if some regions of the country are too. It also would seem as if the benefits are likely to be distributed unequally (NRAC, 1981, p.22).

The background section concludes with recognition of the fact that the problem is extremely complex and has ramifications "all the way from individuals to the highest level of policy making". As well, the problem of confronting unemployment is rendered difficult because "the information available is extremely limited and possibly inaccurate" (NRAC, 1981, p.24). Thus in the section which follows, the Working Party offers twenty six research recommendations covering research policy and practice generally, policy research, and research into the conditions and circumstances of unemployed people themselves. These are presented in a clear and concise style free of the tedious officialese often found in such documents. It is unfortunate that more attention has been paid to the "Background" section than to the Report's recommendations.

All recommendations in as far as they provide advice and suggestions as to remedies for circumstances which need improvement and reform necessitate a degree of criticising discourse. The Report's recommendations are no exception. Each recommendation is to a degree a remonstrance upon the unfortunate state of affairs which characterise social policy, social policy analysis and social science generally in New Zealand. If the NRAC can be said broadly to pursue a science for policy in its alignment towards, acceptance of, and devotion to "a large proportion of science resources of work directed towards (government) goals" (NRAC, 1980, p.4), its "Committee D", the social sciences committee, has indeed a policy for science in the Working Party's Report.

The Report suggests four fundamental weaknesses typical of research with respect to employment and unemployment in New Zealand. Firstly, research relevant to policy is both limited and extremely rare. Secondly there is a lack of appropriate data bases for decision making in either the extent or the composition of unemployment. Thirdly, there is a lack of co-ordination and direction between the different agencies that deal with unemployment, caused by the lack of an integrated organisational structure charged with the responsibility for employment and unemployment. Also there is no current provision for open access to information which the various agencies produce. Lastly there are no appropriate links between the research community and the makers of policy. Thus the Report recommends that "provision be made for an employment/unemployment research co-ordinating body that is wide ranging and reflects the diversity of public and private sector interests" (NRAC, 1981, p.27).

The Report then continues to outline its substantive recommendations well aware that research in and of itself will not necessarily solve the problem of unemployment. But as the authors point out solutions which do not have "the benefit of knowledge and understanding of the likely causes and effects are more prone to fail than succeed" (NRAC, 1981 , p.27). In acknowledging that social research can be put to misuse the writers caution against using research as "an excuse for avoiding to take remedial and reformative action". They also recognise that research in this area can be longitudinal and thus take some time in producing results and conclusions. This should not be used as an excuse "to suspend action pending the outcome of research" which would "make a mockery of the situation". Although such research cannot provide instant "palliatives" it can have a continuous use by providing analysis as regards the "quality of action and decision making over time". They also point to the necessary lag of time between the identification of a "researchable problem, researching it, producing the results and incorporating them into policy and translating them into action" (NRAC, 1981, p.28). 
Next the Report recalls the complexity of the relationships between unemployment and the economy, national development policies, social welfare provisions, social justice and the "happiness and well being of individuals within society" which it outlined in the "Background" section. Such complexity suggests three broad research strategies which are:

1. Research into the conditions of the employed/unemployed with a view to alleviating the impact of adverse conditions - a compensatory strategy.

2. Research into the existing labour market with a view to reversing undesirable tendencies - a curative strategy.

3. Research into the causes of unemployment with a view to eliminating them - a preventative strategy.' (NRAC, 1981, pp.28-29).

At times the writers seem to assume what their proposed research strategies would set out to establish and this is quite understandable given the problem they address. However having established the causes of particular social problems, it does not necessarily follow that a prognosis, nor cure, for that matter, is found. The Report's treatment of cause, consequence and prevention relies more on assertion than argument. The assumption that the discovery of the causes of unemployment will necessarily lead to its elimination is at the very least a tenuous one. The Report is reluctant to recognise that research may well reveal that there is no cure apart from continual ameliorative action within a social and economic system such as New Zealand's.

The research strategies are seen in three differing contexts: the national economy, the labour market and the individual. Further to this "those that compensate will not cure, those that cure will not prevent, but those that prevent will avoid the necessity for either cure or compensation". The prevention which precludes the need for cure lies in a fundamental questioning of the "decisions governing the directions of New Zealand's economic and social development". These in turn are "being taken without adequate research into the assumptions upon which the decisions are based" (NRAC, 1981, p.29). The question the Report confronts here is to what degree the unintended consequences of social action, in this case increases in redundancies and unemployment, can be anticipated before the fact. A notoriously difficult question to answer.

It is to the Working Party's credit that they point to the need for such an analysis of policy formation and execution. Whether or not the social sciences by themselves can provide the required preventative strategies though is a moot point and probably the request entails a burden which is beyond their capacity to bear by themselves. The continued collapse of Keynesian policies with respect to the manipulation of budgetary aggregates is evidence enough of this. In New Zealand, unemployment is still dealt with by the use of budget deficits which supposedly generate aggregate demand. The tactic has failed. The political oppositions bemoan such deficits at the time of particular budgets yet promise the earth and even larger budget deficits during the run up to an election.

The Working Party's recommendations are nevertheless based on three sound notions: that the prime cause of unemployment cannot be found among the population suffering from it; that there is inadequate information and data which can explain the characteristics and dynamics of employment and unemployment within New Zealand; and that the highest priority should be accorded to research that deals with the causes of unemployment. To this end they divide their recommendations into three sections, the first concerns policy, the second focuses on the ramifications of and for the unemployed and lastly they outline the specific research designs and methods, required to produce fruitful results. The Report points out that social research is not necessarily the exclusive domain of specialists and that "a reservoir of research assistance (is) to be found in various sections of the community". It has in mind "the unemployed themselves, beneficiaries, students and others who with appropriate guidance, organisation and management would provide useful research pay-offs" (NRAC, 1981, p.38). 


\title{
Conclusions
}

Ironically it was Marx who expressed an almost indefatigable faith in the ability of officially appointed members of what are now Royal Commissions and various departmental bodies such as commissions, committees and working parties "to get to the truth" about social and economic conditions which exist in various societies and what is more to record part of that truth in the form of "social statistics". Never one to miss the ironies of history himself, he explains in the preface to the first German edition of Capital that the truth was being unravelled by Royal Commissions and others at work in the very service of that appropriating instrument of the ruling class, the English bourgeois state:

\begin{abstract}
The social statistics of Germany and the rest of Continental Western Europe are, in comparison with those of England, quite wretched. But they raise the veil just enough to let us catch a glimpse of the Medusa's head behind it. We should be appalled at our own circumstances if, as in England, our governments and parliaments periodically appointed commissions of inquiry into economic conditions; if these commissions were armed with the same plenary powers to get at the truth; if it were possible to find for this purpose men as competent, as free from partisanship and respect of persons as are England's factory inspectors, her medical reports on public health, her commissioners of inquiry into the exploitation of women and children, into conditions of housing and nourishment, and so on. Perseus wore a magic cap so that the monsters he hunted down might not see him. We draw the magic cap down over our own eyes so as to deny that there are any monsters (Marx, 1867, p.91).
\end{abstract}

Modern opinion however is less enthusiastic; and as regards the veracity, validity and reliability of such reports, is positively cynical. "They can be seen as tactical devices to defray government activity, to postpone legislative or other action while simultaneously demonstrating that particular problems are under administrative review and control" and "they can therefore provide a period where a problem can be held in abeyance" (Burton and Carlen, 1979, p.7). The individual members of such committees are no doubt more sanguine as regards their roles, tasks and objectives but Burton and Carlen continue:

Moreover the recommendations of a report (when not "white-washes"), being advisory, can be and frequently are ignored. The potentially inconsequential outcome of a report is not conducive to restoring public confidence. Again as the research role of these committees should be unnecessary given, the development of state professionalism, the reports perform "merely" rhetorical functions (1979, p.7).

In being unaware of their merely "rhetorical" function did the writers of the NRAC Report go searching naively for the "truth", and in discovering some produce "a load of garbage"? If we are to believe a later conclusion of Burton and Carlen's, the NRAC Working Party has failed miserably where Link Consultants have excelled to the tune of $\$ 37,000$ :

The task of inquiries into particular crises is to represent failure as temporary, or no failure at all, and to re-establish the image of administrative and legal coherence and rationality. One of the political desiderata of official discourse is therefore to retain the intellectual confidence of parties, elites and functionaries within the state apparatuses. To create a discourse of unity and cohesion between parties to the power bloc through the production of periodic manifestos demonstrating the state's sovereign reason (1979, pp.48-49).

The figure of $\$ 37,000$ is the only identifiable price for the production of the Government's Jobs and people for which Link Consultants were contracted to compile a list of people and organisations involved in employment and to prepare a research document for the Minister of Labour. The cost of printing, distribution and staff time have not been made public. Nor can Jobs and people be called "Link's report" as the latter underwent many changes as it did the rounds of Ministers and Departments before publication (NBR, 13 July 1981). 
During the twenty five years between 1947 and 1971 there were twenty six Royal Commissions and fifty commissions of inquiry in New Zealand (Dept. of Internal Affairs, 1974). No one has counted the number of Working Parties. Chapman $(1973$, p.174) has pointed out that with respect to British central government the main difference between Royal Commissions and the various departmental bodies, such as commissions, committees and working parties is in matters of prestige and status. Thus although the NRAC has released the Working Party's Report it is not available in Government Bookshops. Instead one has to write to the NRAC and request a copy. After much heated debate in Parliament, the Minister of Science and Technology, Dr Shearer announced that "the report would be released to interested parties on request" (NZ Herald, 21 July 1981). Obviously the Report's authors intended it to have a wide circulation and foresaw their report becoming a focus for public debate.

The Report was written in a largely jargon-free language and consequently has a lucid and straightforward style. It has been a focus for debate more in the media, by politicians and various departmental experts rather than a widely circulated and considered document. Its terms of release have effectively mothballed it, and the Springbok tour doubtlessly provided much better copy. Although it will probably be "rediscovered" when the final 1981 Census figures concerning those "unemployed and seeking work" become available, if not by the politicians at least by the media.

To my mind the Report's fundamental flaw lies in its lucid language. The contending and contentious issues which beset politics require a bureaucratic language sensitive to what politicians and their supposed experts regard as legitimate. The background assumptions for authors of such reports are found in the lexicons of either the law or economics. The authors of the NRAC Report seem to have missed this fundamental point. The language of their Report is oppositional in substance and humanitarian in sentiment. The Report's authors seem to be unaware that in the political arena the politics of unemployment as an issue supersedes the politics of the unemployed as a group. Consequently conservative politicians have seen the Report more as advocacy than advice, with the result that its important recommendations were largely disregarded during the commotion which followed its unofficial release. The language of humanitarian sentiment is one which conservative Prime Ministers evidently cannot afford to comprehend let alone take seriously. Rather than admit this however it is usually sent packing as "garbage".

Nevertheless to explain how the Report became labelled as garbage is not to justify it being called so. The flak which its unofficial release drew demonstrates the need for such a Report in the first place. To put it quite simply nobody seems to know what they are talking about with respect to unemployment, let alone the conditions under which the unemployed live, and thus research along the lines of those recommended in the Report is long overdue. Also supposed "garbage" should be allowed the test of publication without the need to contract private sector consultants to set the record straight.

Finally, it is a pity that in politics personalities often get in the way during the battle of reason versus enthusiasm. The presence of Ian Shirley and Alf Kirk on the Working Party did not augur well in terms of the Report's ultimate reception by and acceptability to the National Government. The former had collided with the Prime Minister in 1976 whilst working for the Auckland City Council as a Community Advisor, whilst the latter who is now employed as a research officer for the Federation of Labour used to be a Treasury economist. Lastly Suzanne Snively was defined or condemned by her relationship to her husband, one Ian Fraser. No doubt every time these three put pen to paper the result is "garbage"!

\section{References}

Auckland City Council (1980) Employment: survey results Auckland, Department of Planning and Community Development.

Braae, G.P. (1978) The effects of unemployment benefits on the rate of unemployment 
in New Zealand. In H.G. Grubel and M.A. Walker (Eds) Unemployment insurance: global evidence of its effects on unemployment: proceedings of an international conference held in Vancouver, B.C. Canada. Vancouver, The Fraser Institute.

Burton, F., and Carlen, P. (1979) Official Discourse: On discourse analysis, government publications, ideology and the state London, Routledge and Kegan Paul.

Casson, M. (1979) Youth unemployment London, Macmillan.

Chapman, R.A. (Ed) (1973) The role of Commissions in policy-making, London, George Allen and Unwin.

Department of Internal Affairs (1974) Royal Commissions and Commissions of Inquiry Wellington.

Dissent (1981) Facts we dare not forget: Excerpts from a neglected government report on poverty and unemployment to which the New Administration will surely pay no attention, Spring: 64-172.

Easton, B. (1979) Social policy and the welfare state in New Zealand Auckland, George Allen and Unwin.

Field, F. (Ed) (1979) The conscript army London, Routledge and Kegan Paul.

Forer, P. (1980) Job creation and temporary employment: The last five years New Zealand population review 6(3):33-37.

Gidlow, B. (1979) Unemployment New Zealand social worker 3(2):2-11.

Hayes, J. and Nutman, P. (1981) Understanding the unemployed: The psychological effects of unemployment London, Tavistock.

Jenkins, C. and Sherman, B. (1979) The collapse of work London, Eyre Methuen.

Jobs and people: the Government's employment strategy (1981) Wellington.

Labour and employment gazette (1982) 32(1).

Marx, K. (1976) Capital: Vol. 1 Harmondsworth, Penguin Books.

Mulkay, M. and Milic, V. (1980) The sociology of science in East and West Current sociology 29(3):1-342.

National Research Advisory Council (1980) Report for the year ended 31 March Wellington.

National Research Advisory Council (1981) Report for the year ended 31 March Wellington.

National Research Advisory Council (1981) Report of the Working Party on research into employment with special emphasis on youth employment (Xerox).

New Zealand Parliamentary Debates (1981) Vol. 348, No. 12.

O.E.C.D. (1979) Measuring employment and unemployment Paris.

O.E.C.D. (1980) New Zealand economic survey Paris.

Ovenden, K. (1979) The politics of funding scientific research. In W. Green (Ed) Focus on social responsibility in science Christchurch, New Zealand Association of Scientists.

Shannon, P. and Webb, B. (Eds) (1980) Unemployment and New Zealand's future, proceedings of the second social policy school, 16-18 February, 1979 University of Otago, University Extension.

Showler, B. and Sinfield, A. (Eds) (1981) The workless state Oxford, Martin Robertson. Sinfield, A. (1981) What unemployment means Oxford, Martin Robertson.

Thompson, E.P. (1980) Writing by candlelight London, Merlin.

Walsh, C. (1978) Unemployment in New Zealand: An errors in variables approach to measuring the number of unemployed New Zealand economic papers 12:13-48.

Windschuttle, K. (1980) Unemployment: 'a social and political analysis of the economic crisis in Australia Victoria, Penguin Books. 